\title{
Studies on Environmental Quality Impact Assessment of Waste Disposed in Idye Detention Basin, Makurd North Central Nigeria
}

\section{Azua $\mathrm{ET}^{1}$, Akaahan $\mathrm{TJA}^{1^{*}}$ and Akogwu $\mathrm{SA}^{2}$}

${ }^{1}$ Department of Biological Sciences, University of Agriculture, PMB 2373 Makuedi Benue State, Nigeria

${ }^{2}$ Department of Biological Sciences, Federal University PMB 1005, Gashua Yobe State, Nigeria

*Corresponding author: Akaahan TJA, Department of Biological Sciences, University of Agriculture, PMB 2373 Makuedi Benue State, Nigeria, Tel: +2348037737675; E-mail: terngu.adaga@gmail.com

Received: February 20, 2018; Accepted: March 10, 2018; Published: March 15, 2018

Copyright: (c) 2018 Azua ET, et al. This is an open-access article distributed under the terms of the Creative Commons Attribution License, which permits unrestricted use, distribution, and reproduction in any medium, provided the original author and source are credited.

\begin{abstract}
The Idye detention basin in was constructed to prevent the annual flood in the Idye area which is the major settlement within the main settlement of Makurdi. All the same the resident of Makurdi metropolitan area have turn it to a waste dump site without the injurious effects of these wastes on the environment and the public health. To ascertain the environmental quality of the basin water samples were collected downstream along the basin in Makurdi and analyzed for physicochemical using standard methods. The physicochemical characteristics of the basin during the investigation time were conductivity, TDS, surface water temperature, turbidity, TSS, $\mathrm{pH}$, nitrate, Sulphate, phosphate, DO, BOD and COD were $289.00 \pm 158.35 \mu \mathrm{S} / \mathrm{cm}, 168.00 \pm 95.00 \mathrm{mg} / \mathrm{L}, 24.00 \pm 0.26^{\circ} \mathrm{C}, 12.58$ $\pm 14.64 \mathrm{NTU}, 60.00 \pm 65.07 \mathrm{mg} / \mathrm{L}, 5.54 \pm 0.21,6.80 \pm 3.72 \mathrm{mg} / \mathrm{L}, 16.60 \pm 7.44 \mathrm{mg} / \mathrm{L}, 2.26 \pm 0.83 \mathrm{mg} / \mathrm{L}, 3.65 \pm 1.51$ $\mathrm{mg} / \mathrm{L}, 3.86 \pm 0.96 \mathrm{mg} / \mathrm{L}$ and $7.68 \pm 1.37 \mathrm{mg} / \mathrm{L}$ respectively. The results of the physico-chemical parameters of the water samples sampled downstream along the detention basin depict that conductivity varied from 45.00-409.00 $\mu \mathrm{S} / \mathrm{cm}$, TDS ranged from $22.00-267.00 \mathrm{mg} / \mathrm{L}$, Surface water temperature differed from $24.00-25.400^{\circ} \mathrm{C}$, turbidity ranged from 4.16-38.50 NTU, TSS varied from $25.00-175.00 \mathrm{mg} / \mathrm{L}$ and $\mathrm{pH}$ ranged from $6.35-7.41$ across the sample location along the idye detention basin. Similarly, nitrate varied from $2.50-12.10 \mathrm{mg} / \mathrm{L}$, sulphate differed from $10.00-29.00 \mathrm{mg} / \mathrm{L}$ and phosphate concentration along the study sites of the detention ranged from $1.20-3.20 \mathrm{mg} / \mathrm{L}$ at the stations during the course of the study. The DO characteristics along the sample location of the Idye detention basin in Makurdi Nigeria, during the time of this investigation ranged from $1.900-3.50 \mathrm{mg} / \mathrm{L}$, BOD, varied from 2.40-4.50 $\mathrm{mg} / \mathrm{L}$ and COD differed from 5.60-9.30 $\mathrm{mg} / \mathrm{L}$ across the sample locations of the detention basin. The result of the t-test analysis at $5 \%$ was significant with conductivity, TDS, surface water temperature, nitrate, sulphate, phosphate, DO, BOD and COD $(\mathrm{P}<0.05)$. However, it was not significant at 0.05 level of significance with $\mathrm{pH}$, turbidity and TSS during the course of the study $(p>0.05)$. The study conclude that the basin is contaminated with some physio-chemical parameter and recommends that waste should not be dumped indiscriminately into the basin and the sanitation authority as the regulatory body, ensure the protection of the basin to safe guide public health integrity and environment within the vicinity of the basin in Makurdi.
\end{abstract}

Keywords: Idye; Detention; Basin; Makurdi; Physicochemical

\section{Introduction}

A detention basin or retarding basin is an excavated area installed to protect against flooding waters to spill on the land. In some instances, it is constructed to down streams erosion as it was observed in the Idye of Makurdi. This is achieved due to the storing of water capacity by the basin for a limited period of time as in the case of the Idye village which is flood prone area in Makurdi, North central Nigeria. The basin is storm water runoff best management practices that provide general flood protection and can also control extreme flood which usually was a yearly occurrence environmental menace in Idye village [1]. It is either dry detention or dry extended detention basin which is surface water facilities intended to provide for temporary storage of water of storm water runoff to reduce downstream water quantity impact [1]. There is increase in waste consciousness in the environment in which man lives. The production of solid waste, rubbish garbage and sewage are on daily basis in the Nigerian Urban settlements without appropriate dumping or disposal strategies as it is done in Makurdi, North central Nigeria [2]. It is the culture of the under developed of disposing these wastes into the available water ways without taking into the cognizance its effects on the biodiversity of the environment [3]. Okorie et al. postulate that the disposal of untreated hospital wastes in the water ways is unwholesome practice and an environmental threat and risk to public health [4]. Similarly, Omole et al. reported that the dumping of wastes with insufficient waste management practice impacting negatively on the environment and human residents in Nigeria in habiting the cities located on the coast in Nigeria as a very poor habit and waste disposal management measures as it is practice in Makurdi [4,5]. All the same the management of waste of solid waste is a complex issue globally. In the industrialized and developed Nations the challenge of the management solid waste through the process of collection, transportation and disposal are well understood, accepted and sustainable Nartey et al. [6]. This is because the poor disposal practice of solid waste into the surface water sources with toxic effects of the disposed waste into the water ways may bio stored in the body system of aquatic organisms with long term adverse effects [7]. It is paramount that efficient and better strategies in the management of the waste is adopted to forestall the bio stored adverse effects in the future [8]. As a result of the menace of poor waste disposal practices in Nigeria, effective legislation with severe punishment and penalty should be implemented. At the same time, the public awareness campaign on the danger of improper waste disposal 
mechanism should be on continuous flow in the society for the general public to understand in clear terms the menace associated with indiscriminate dumping of municipal wastes on the environment without adequate treatment [9].

The Idye detention basin in Makurdi North Central Nigeria was designed mainly for the control of the annual flood was the reoccurrence environmental disaster in the Idye village with its consequent negative impact on the people of the area in Makurdi, Nigeria. All the same the Makurdi residents living along the basin and outside the basin have turn it to their waste disposal sites for different types and sources of wastes from the anthropogenic activities without recourse of this un wholesome attitude due to the injurious effects of the waste to the groundwater and public health risk. It is a usual practice for all kinds of waste to be dumped into this basin all year round. This study is indispensable because the basin is located within the major Makurdi settlement of High-level cadastral area with a high population of people living around and within the basin. The risk of groundwater contamination which is one of the major domestic water in the area and risk of outbreak of tropical diseases like malaria and typhoid fever is very high among the populace of the basin in Makurdi. The study is to assess the physicochemical quality of the water of the Idye detention basin that flows all year round with its environmental menace of the people living along the basin and Makurdi at large during the study period.

\section{Materials and Methods}

\section{Description of the study area}

Idye detention basin covers an area of fifty-eight square meters and have its origin from River Benue where it take its course and passes through Wurukum roundabout where it meanders through zone four (4) police headquarters, and through Idye village where it picked its name from and continues through Adeke-mobile barrack where it finally re-enters River Benue again at Adeke axis (Figure 1). Idye detention basin is a wide area measuring one hundred (100) square meters in length and forty meters in diameter. To determine the Physico-chemical parameter of this area five samples of water collection were selected at the following sections of the basin: Wurukum, behind N.K.S.T. Church low level, Ishaya Bakut road, adjacent zone 4 police head-quarters along Old Otukpor road in Makurdi and river Benue along as control along the Idye flood basin for this study and were subjected to Physico-chemical analysis using standard laboratory techniques to determine the physico-chemical parameters of the basin.

The wurukum, location is at the centre of the town where basin takes its course from River Benue. It is also closed to the Wurukum market where it takes its name and untreated wastes are collected and deposited into the basin through Wurukum. The NKST Church lowlevel of the basin is with interconnection between Wurukum roundabout and the NKST church. The waste generated at this point equally flows the same direction downstream along the basin as well as waste generated within the vicinities are emptied into the basin causing pollution. The waste from Wurukum and behind the Church flows downstream and joins the Ishaya Bakut Road, here a lot of automobile are being carried out like repairs and washing of cars are washed into the basin with runoff of agricultural chemicals due to the agricultural activities that are carry out. The area is with municipal waste dumpsites that washed into the basin and the people consider it as a reservoir for their domestic wastes including open defecation. The wastes produced by either of these activities are empties into the basin. It then flows adjacent to Zone 4 police headquarters, as the basin meanders and empties back into river Benue from mobile barracks down wards at Adeke village in Makurdi. The wastes are of various kinds, households, electronic, automobile, Agricultural, waste from the human feces and among others are dumped without control into the basin. The sequence of this movement of waste along this path has equally impacted negatively on the water quality of River Benue. The water current of Idye basin depends on the time of the year.

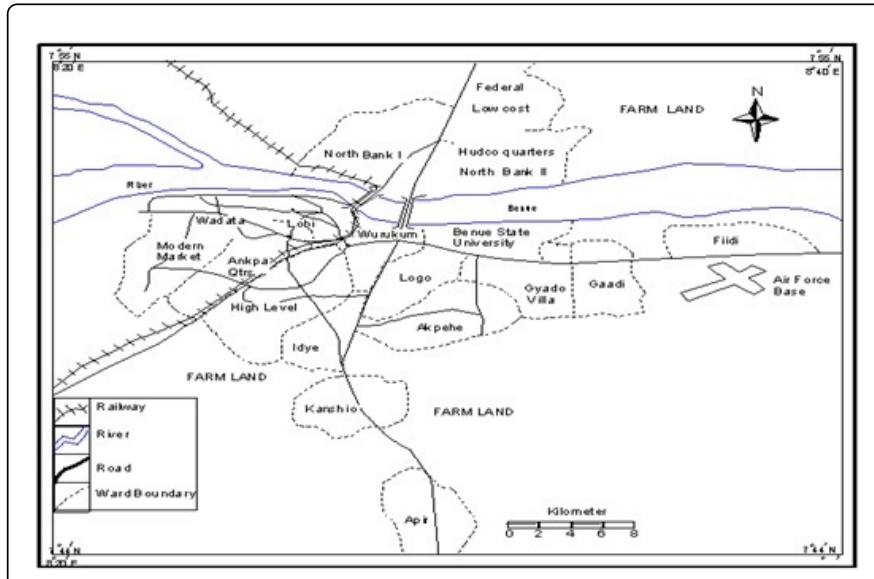

Figure 1: Map of Makurdi Showing Major settlement and River Benue.

\section{Water sample collection and analysis}

Water samples for physico-chemical analysis were collected between 8:00 am and 12:00 noon on each sampling day. The samples were collected in bottles of $1,500 \mathrm{~mL}$ capacity at the depth of the idye detention flood basin. Sampling bottles and containers were rinsed three times with the Idye flood basin water at the sampling site before collection. Each sample container was treated according to the analysis to be carried out on it on the field before they were transported to the laboratory. Surface water temperature, TDS, Conductivity, DO and $\mathrm{pH}$ were determined in situ on the field with measuring meters, while nitrate, chloride, bicarbonate, sulphate, phosphate, TSS, turbidity, colour, $\mathrm{COD}$ and $\mathrm{BOD}$ were examined in the laboratory using standard methods [10].

\section{Data analysis}

Microsoft excel 2007 was used for graphical illustrations. Descriptive statics were determined using SPSS version 20 with student $\mathrm{t}$-test was determined to test the significant difference among means of water quality parameters across stations along the Idye detention basin.

\section{Results}

The results in Table 1 are the variation in the physico-chemical characteristics in the Idye detention basin in Makurdi, North central Nigeria. A perusal at the results showed that the mean concentration values of the physic-chemical parameters during the study time of conductivity, TDS, surface water temperature, turbidity, TSS, $\mathrm{pH}$, nitrate, sulphate, phosphate, DO, BOD and COD were $289.00 \pm 158.35$ $\mu \mathrm{S} / \mathrm{cm}, 168.00 \pm 95.00 \mathrm{mg} / \mathrm{L}, 24.00 \pm 0.26^{\circ} \mathrm{C}, 12.58 \pm 14.64 \mathrm{NTU}, 60.00$ $\pm 65.07 \mathrm{mg} / \mathrm{L}, 5.54 \pm 0.21,6.80 \pm 3.72 \mathrm{mg} / \mathrm{L}, 16.60 \pm 7.44 \mathrm{mg} / \mathrm{L}, 2.26 \pm$ 
Citation: Azua ET, Akaahan TJA, Akogwu SA (2018) Studies on Environmental Quality Impact Assessment of Waste Disposed in Idye Detention Basin, Makurd North Central Nigeria. Adv Recycling Waste Manag 3: 155. doi:10.4172/2475-7675.1000155

Page 3 of 5

$0.83 \mathrm{mg} / \mathrm{L}, 3.65 \pm 1.51 \mathrm{mg} / \mathrm{L}, 3.86 \pm 0.96 \mathrm{mg} / \mathrm{L}$ and $7.68 \pm 1.37 \mathrm{mg} / \mathrm{L}$ respectively. The data presented in Table 2 is the physico-chemical quality of water samples at Idye detention basin in Makurdi Benue state, Nigeria. The results of the physico-chemical parameters of the water samples sampled downstream along the detention basin depict that conductivity varied from $45.00-409.00 \mu \mathrm{S} / \mathrm{cm}$, TDS ranged from 22.00-267.00 $\mathrm{mg} / \mathrm{L}$, Surface water temperature differed from $24.00-25.400^{\circ} \mathrm{C}$, turbidity ranged from $4.16-38.50 \mathrm{NTU}$, TSS varied from $25.00-175.00 \mathrm{mg} / \mathrm{L}$ and $\mathrm{pH}$ ranged from 6.35-7.41 across the sample location along the idye detention basin. Similarly, nitrate varied from $2.50-12.10 \mathrm{mg} / \mathrm{L}$, sulphate differed from $10.00-29.00 \mathrm{mg} / \mathrm{L}$ and phosphate concentration along the study sites of the detention ranged from 1.20-3.20 mg/L at the stations during the course of the study. The DO characteristics along the sample location of the Idye detention basin in Makurdi Nigeria, during the time of this investigation ranged from 1.900-3.50 mg/L, BOD, varied from $2.40-4.50 \mathrm{mg} / \mathrm{L}$ and COD differed from $5.60-9.30 \mathrm{mg} / \mathrm{L}$ across the sample locations of the detention basin.

\begin{tabular}{|c|c|c|c|c|c|c|}
\hline Parameter & Unit & Minimum & Maximum & Range & Mean & Std dev \\
\hline Conductivity & $\mu \mathrm{S} / \mathrm{cm}$ & 46 & 450 & 404 & 289.4 & 158.35 \\
\hline TDS & $\mathrm{mg} / \mathrm{L}$ & 22 & 267 & 245 & 168 & 95 \\
\hline Surface Temp. & ${ }^{\circ} \mathrm{C}$ & 24 & 25.4 & 1.4 & 24 & 0.26 \\
\hline Turbidity & NTU & 4.16 & 38.5 & 34.34 & 12.58 & 14.64 \\
\hline TSS & $\mathrm{mg} / \mathrm{L}$ & 18 & 175 & 157 & 60 & 65.07 \\
\hline $\mathrm{pH}$ & & 6.35 & 7.41 & 1.06 & 5.54 & 0.21 \\
\hline Nitrate & $\mathrm{mg} / \mathrm{L}$ & 2.5 & 12.1 & 9.6 & 6.8 & 3.72 \\
\hline Sulphate & $\mathrm{mg} / \mathrm{L}$ & 10 & 29 & 19 & 16.6 & 7.44 \\
\hline Phosphate & $\mathrm{mg} / \mathrm{L}$ & 1.2 & 3.2 & 2 & 2.26 & 0.83 \\
\hline DO & $\mathrm{mg} / \mathrm{L}$ & 1.9 & 5.5 & 3.6 & 3.65 & 1.51 \\
\hline BOD & $\mathrm{mg} / \mathrm{L}$ & 2.4 & 4.89 & 2.49 & 3.86 & 0.96 \\
\hline COD & $\mathrm{mg} / \mathrm{L}$ & 5.66 & 9.3 & 3.64 & 7.68 & 1.37 \\
\hline
\end{tabular}

Table 1: Variation in the Physico-chemical Characteristic in Idye Detention Basin at Makurdi.

\begin{tabular}{|c|c|c|c|c|c|}
\hline Parameters/(Units) & Wurukum & $\begin{array}{l}\text { Behind N.K.S.T, Church } \\
\text { low level }\end{array}$ & Ishaya Bakurt Road & $\begin{array}{l}\text { Zone } 4 \text { police head } \\
\text { quarters }\end{array}$ & River Benue \\
\hline Conductivity $(\mu \mathrm{s} / \mathrm{cm})$ & 45 & 409 & 283 & 259 & 46 \\
\hline TDS (mg/L) & 267 & 241 & 162 & 150 & 22 \\
\hline Temperature $\left({ }^{\circ} \mathrm{C}\right)$ & 25.1 & 24 & 24.6 & 25.3 & 25.4 \\
\hline Turbidity (NTU) & 4.16 & 4.75 & 5.93 & 9.54 & 38.5 \\
\hline TSS (mg/L) & 18 & 33 & 25 & 46 & 175 \\
\hline $\mathrm{pH}$ & 7.41 & 6.81 & 6.46 & 6.35 & 6.7 \\
\hline Nitrate (mg/L) & 12.1 & 8.4 & 6.7 & 4.3 & 2.5 \\
\hline Sulphate (mg/L) & 10 & 12 & 15 & 17 & 29 \\
\hline Phosphate (mg/L) & 1.2 & 3.2 & 1.8 & 2.1 & 1.2 \\
\hline $\mathrm{DO}(\mathrm{mg} / \mathrm{L})$ & 1.9 & 2 & 2.1 & 2 & 3.5 \\
\hline $\mathrm{BOD}(\mathrm{mg} / \mathrm{L})$ & 2.4 & 3.8 & 4.5 & 3.4 & 4.1 \\
\hline $\operatorname{COD}(\mathrm{mg} / \mathrm{L})$ & 5.6 & 7.2 & 9.3 & 7.84 & 8.4 \\
\hline
\end{tabular}

Table 2: Physico-chemical quality of Water at Idye Detention Basin in Makurdi.

The data presented in Figure 2 is the physical quality of the water samples downstream along the different sampling locations of the Idye detention basin in Makurdi, Nigeria. A perusal at the result indicates that the concentration of conductivity was highest among all the 
parameters while $\mathrm{pH}$ was the lowest during the time of investigation. The physical parameters of the water samples decrease from Wurukum location of the detention basin into the river Benue where the basin originated and flow downwards through Wurukum and linked the Idye village to the mobile barracks and finally and the downstream of River Benue where it empties as the river flows to Lokoja in Kogi state, Nigeria. All the same the physical parameters decrease from Wurukum downstream along the basin except at for TSS that was highest at the River Benue sites and lowest at the Wurukum location of the basin during the study time.

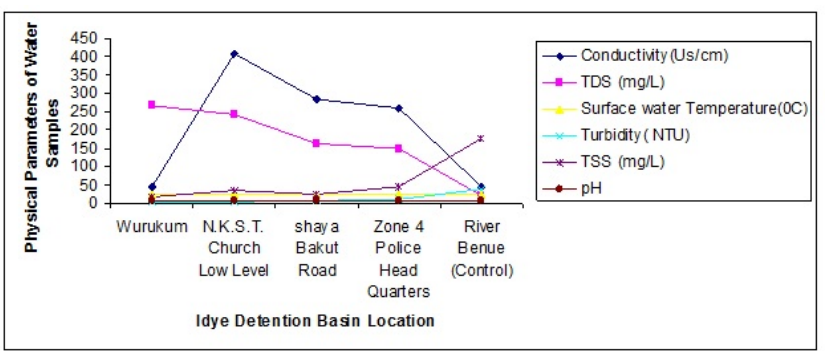

Figure 2: Physical Quality of Water Samples at Idye Detention Basin.

The data in Figure 3 depict the Chemical Quality of Water Samples at Idye Detention Basin. A critical look at this result revealed that the concentration of sulphate was the highest among the parameters while phosphate was the lowest. All the same phosphate concentration at the river Benue site was the highest and the lowest at the Wurukum station. There was slight increase in phosphate concentration along the basin while nitrate decreases from the Wurukum to River Benue station during the period of the study. The result presented in Figure 4 is the Organic Pollution Indicators of Water Samples at Idye Detention Basin. A careful look at the result showed that the COD was the highest in its values among the other parameters while the DO was the lowest along the stations of the Idye detention basin. Nevertheless, the organic pollution indicators increased from Wurukum to river Benue downstream along the basin. The result of the t-test analysis at $5 \%$ was significant with conductivity, TDS, surface water temperature, nitrate, sulphate, phosphate, DO, BOD and COD $(\mathrm{P}<0.05)$. However, it was not significant at 0.05 level of significance with $\mathrm{pH}$, turbidity and TSS during the course of the study ( $>00.05)$.

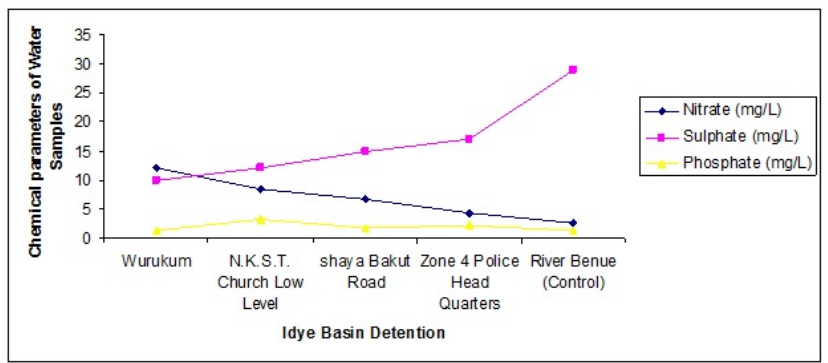

Figure 3: Chemical Quality of Water Samples at Idye Detention Basin.

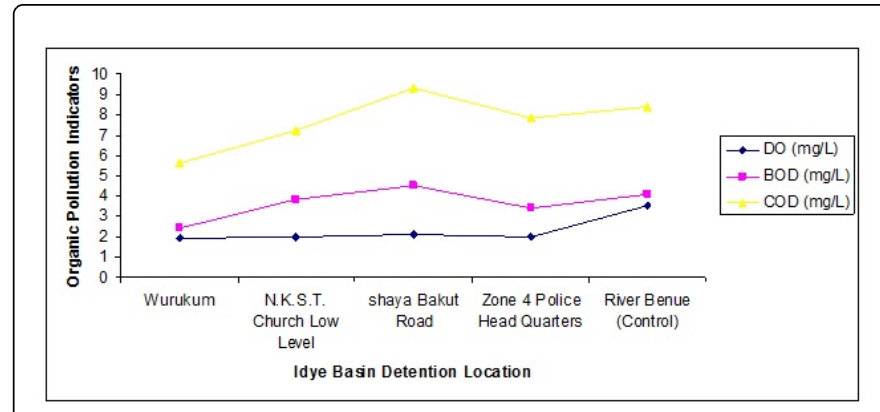

Figure 4: Organic Pollution Indicators of Water Samples at Idye Detention Basin.

\section{Discussion}

The indiscriminate dumping of refuse in the water ways is a common practice among the people of the cities in Nigeria without minding the injurious effect of the waste on the environmental component. This situation is not different from what is obtainable in Idye detention basin in Makurdi. Ololade reported higher mean values of sulphate and nitrate in the surface waters dumped with household waste and lower mean value of phosphate as compared to the finding of this study [2]. Their results differ significantly from the result of this present investigation. This difference may be due largely to the nature and the waste contents dumped into the different surface water bodies. The mean DO of this study was low which indicate clearly that organic wastes are dumped into the basin. All the same, Omole et al. reported a far low mean value of $2.24 \mathrm{mg} / \mathrm{L}$ of DO in Illo river, Ota Ogun state, Nigeria that is dumped with wastes which varies significantly with the finding of this study in Makurdi, Nigeria [3,4]. Low DO values of less than $5.00 \mathrm{mg} / \mathrm{L}$ will not support the living and growth of aquatic fauna in the surface water and it is indication of organic wastes dumped into the surface water body. All the same they reported very low mean values of nitrate, phosphate and conductivity in the river IIIo but very high value of BOD (312.90 mg/L) which still differs significantly from the result of this present study. Nkwoacha et al. reported higher mean values of turbidity, conductivity, total solids and suspended solids of solid waste dumped on water quality [5]. This result varies significantly from the findings of this study. The time the wastes are dumped and stayed in the surface ways and the product of the wastes make up may be responsible this difference in the surface water bodies at the various time of the studies. All the same the physico-chemical of the water samples for both dry and rainy season (surface temperature, $\mathrm{pH}$ and turbidity) were with higher values in the solid waste dumped sites on surface water systems in Accra metropolitan area, Ghana as compared to the result of this study Nartey et al. [6]. This result is at variance with the finding of this present investigation on the waste dumped in the Idye detention basin Makurdi, North central Nigeria. Similarly, Rashid et al. reported higher values of physic chemical parameters in the surrounding surface water bodies in Bhanpur, Bhopal (M.P.) compared to result of this study in Makurdi [7]. However, a similar range of $\mathrm{pH}$ was reported in Otamiri surface water dumpsites which conform to the result of this study [8]. During the course of this study the mean concentration of conductivity, TDS, nitrate and sulphate were within the WHO recommended value for acceptable drinking water quality [10]. Nevertheless, the mean concentration of turbidity was higher than the WHO recommend standard for drinking water quality [11]. The significance $\mathrm{t}$-test result obtained for conductivity, TDS, surface 
Citation: Azua ET, Akaahan TJA, Akogwu SA (2018) Studies on Environmental Quality Impact Assessment of Waste Disposed in Idye Detention Basin, Makurd North Central Nigeria. Adv Recycling Waste Manag 3: 155. doi:10.4172/2475-7675.1000155

Page 5 of 5

water temperature, nitrate, phosphate, $\mathrm{DO}, \mathrm{BOD}$ and $\mathrm{COD}$ is an indication that the wastes dumped into the Idye detention basin contribute to the concentration of these parameters during the study time. However, the non-significance result of $\mathrm{pH}$, turbidity and TSS may not attribute to the wastes dumped into basin but the makeup of the water quality.

\section{Conclusion}

The findings of this study indicate that physicochemical of the basin is compromised due to the waste dumped into it and may affect the ground water and aquatic biota along the basin thereby affecting the pristine quality of the environment. The study recommends that waste should not be dumped indiscriminately into the basin and the sanitation authority as the regulatory body, ensure the protection of the basin to safe guide public health integrity and environment within the vicinity of the basin in Makurdi.

\section{References}

1. Atlanta Regional Commission (2001) The Georgia Storm Water Management Manual Technical Handbook (1st Edn.,) Atlanta Regional Commission, AMEC Earth and Environmental Centre for Watershed Protection. DEbo and Associates Jordan Jones and Goulding 2: 844.

2. Ololade IA, Adewunmi A, Ologundu A, Adeleye A (2009) Effects of household wastes on surface and ground waters. Intern J Phys Sci 4: 22-29.
3. Omole DO, Isiorho S (2011) Waste management and water quality issues in coastal States of Nigeria: The Ogun state experience. J Sustain Develop Africa 13: 207-217.

4. Okore CC, Ogechukwu NM, Oyekwore BC, Onyewenjo SC, Agaptus UO, et al. (2014) Impact of disposal of hospital waste into Nworie river in Imo state, Nigeria. Intern J Environ Monitor Protec 1: 7-11.

5. Nkwocha EE, Pat-Mbano EC, Nnaji AO (2011) Effect of solid waste dump on river water quality: a paradigm in a Nigeria tropical environment. Intern J Sci Natur 2: 501-507.

6. Nartey VK, Hayford KE, Ametsi SK (2011) Assessment of the impact of solid waste dumped sites on some surface water systems in the Accra, metropolitan area, Ghana. J Water Res Protection 4: 605-615.

7. Rashid D, Duwedi S (2015) Effect of open waste dumping on its surrounding surface water bodies in Bhanpur, Bhopal. Intern J Eng Sci Innov Technol 4: 129-131.

8. Iwuoha GN, Osuji LC, Onwuachu U (2013) Impact of waste dumped on the sediment and surface water quality of Otamiri river, Nigeria. J Appli Sci Enviro Manage 17: 573-575.

9. Butu AW, Msheiha S (2014) Municipal solid waste disposal and environmental issues in Kano metropolis, Nigeria. British J Environl Sci 2: $10-26$.

10. WHO (2004) Drinking Water Guidelines, p: 130.

11. APHA (1999) Standard Methods for Examination of Water and Wastewaters (20th Edn.,) American Public Health Association, APHA, Washington, D.C, p: 1134. 